\title{
Diffusion joining of silicon nitride ceramics
}

\author{
Steffen Dahms ${ }^{\mathrm{a}}$, Felix Gemse ${ }^{\mathrm{a}}$, Ursula Basler ${ }^{\mathrm{a}}$, Hans-Peter Martin ${ }^{\mathrm{b}}$ \\ and Anke Triebert ${ }^{\mathrm{b}}$ \\ a Günter-Köhler-Institut für Fügetechnik und Werkstoffprüfung GmbH, Otto-Schott-Str. 13, 07745 \\ Jena, Germany; sdahms@ifw-jena.de \\ b Fraunhofer Institut Keramische Technologien und Systeme, Winterbergstraße 28, 01277 Dresden, \\ Germany; Hans-Peter.Martin@ikts.fraunhofer.de
}

Received 30 June 2009, in revised form 8 October 2009

\begin{abstract}
High-temperature and wear-resistant ceramics require new joining technologies for manufacturing large-sized and complex components from segments with multi-functional characteristics. Special ceramic foils were developed (LPS-SiC foils - Liquid-Phase-Sintering) for the joining of the non-oxide ceramics - silicon nitride $\mathrm{Si}_{3} \mathrm{~N}_{4}$. Different concentration of sinter additive in the foils has an influence on the sinter temperature. Pressure- and vacuum-tight joints could be produced through diffusion joining by means of adjusted foils, which show a strength high enough for application at the temperatures up to $1600-1700^{\circ} \mathrm{C}$.
\end{abstract}

Key words: silicon nitride, ceramic SiC-foils, liquid-phase-sintering, diffusion joining, diffusion parameters, shear test, joining zone.

\section{INTRODUCTION}

Well-proven methods for the joining of high-performance ceramics such as $\mathrm{Al}_{2} \mathrm{O}_{3}, \mathrm{ZrO}_{2}, \mathrm{Si}_{3} \mathrm{~N}_{4}, \mathrm{AIN}$ or $\mathrm{SiC}$ are soldering procedures (soldering with glass solder, metalizing and soldering or active soldering), bonding procedures, diffusion joining through metal interlayers, diffusion joining without interlayers or laser joining $\left[{ }^{1-3}\right]$.

All these procedures have specific advantages and disadvantages. Application requirements, which combine a high temperature resistance in air with a high stability and leak tightness, can only be met with certain component geometries or through high efforts using special procedures. Particularly, high thermal stress at the temperature of over $1200{ }^{\circ} \mathrm{C}$ in air cannot be avoided in most soldering procedures due to the chemical and thermal instability of the used metal and glass solders. Bonding and trimming procedures do not achieve gas tightness and tend to degrade due to the porosity or the structure in the joining zone. The direct 
diffusion joining without interlayer requires very high joining temperatures and a complex surface preparation and can only be used for simple component geometries $\left[{ }^{4}\right]$.

$\mathrm{Si}_{3} \mathrm{~N}_{4}$ ceramic joints require a joining temperature of $1800^{\circ} \mathrm{C}$. It is shown $\left[{ }^{5,6}\right]$ that the substantial joint can be achieved through diffusion joining without interlayers, provided that the surfaces have a high quality (low surface roughness) and that the surfaces are parallel to each other (Fig. 1). This is necessary in order to guarantee a close contact of the surfaces. The substance-to-substance joining in the solid state is carried out through diffusion processes at high temperatures.

A new procedure for the diffusion joining of the non-oxide ceramics-silicon nitride $\left(\mathrm{Si}_{3} \mathrm{~N}_{4}\right)$ with ceramic foils, consisting sinter additive, shall here be introduced. $\mathrm{Si}_{3} \mathrm{~N}_{4}$ is a high temperature, corrosion and wear resistant ceramic with a high thermal shock resistance of 350-450 K. Therefore interlayer materials with adjusted thermal characteristics were developed.

\section{EXPERIMENTAL}

$\mathrm{SiC}$ is used as a basic component in the foils. Sinter additives such as, e.g., $\mathrm{Al}_{2} \mathrm{O}_{3}, \mathrm{Y}_{2} \mathrm{O}_{3}$ and $\mathrm{SiO}_{2}$ reduce the joining temperatures. These ceramic joining foils are called LPS-SiC foils (Liquid-Phase-Sintering), they are manufactured through a ceramic shaping procedure (doctor-blade-procedure). Foils thickness of $50-200 \mu \mathrm{m}$ could be realized. The stages of the formation of joints using joining foil are shown in Fig. 2.

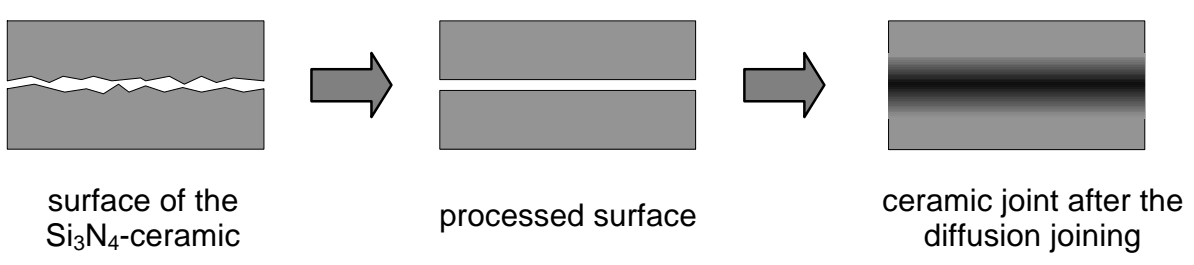

Fig. 1. Diffusion joining without interlayer.

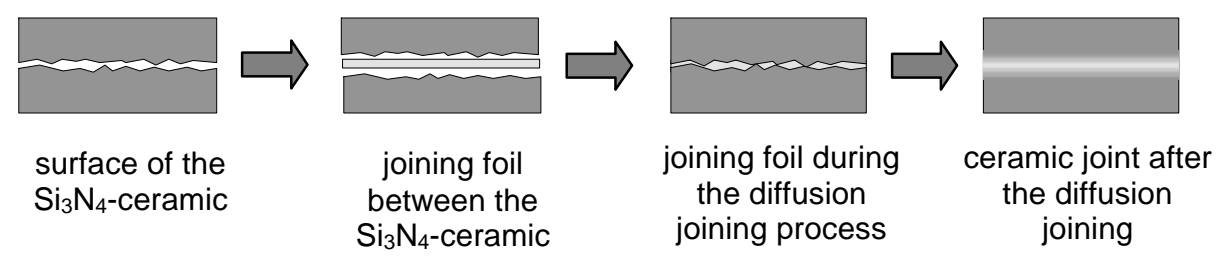

Fig. 2. Diffusion joining with ceramic joining foil. 
Plane and overlapping $\mathrm{Si}_{3} \mathrm{~N}_{4}$-ceramic joints with the dimensions $20 \times 20 \mathrm{~mm}^{2}$ and $20 \times 10 \mathrm{~mm}^{2}$ were produced for the joining tests (Fig. 3). The LPS-SiC foils (foil thickness $50 \mu \mathrm{m}$ ) were positioned between the LPS-Si ${ }_{3} \mathrm{~N}_{4}$-ceramic surfaces. The diffusion joining tests were carried out in a high temperature graphite furnace at joining temperatures of 1500,1600 and $1700^{\circ} \mathrm{C}$ in an argon atmosphere. The heating and cooling rates were $10 \mathrm{~K} / \mathrm{min}$. At $600^{\circ} \mathrm{C}$ an holding was made. The organic constituents are completely burnt out of the LPS-SiC foils. The joining time in all tests was $60 \mathrm{~min}$. During the whole diffusion joining process there was a joining force of $2000 \mathrm{~N}$. The joining tests resulted in solid ceramic joints.

The thermal expansion of the joining parts, being an important quality for the production of low-stress and mechanically stable joints with LPS-SiC foils, was investigated. For these foil laminates, the coefficients of thermal expansion (CTE) were determined with a high temperature dilatometer $\left.{ }^{7}\right]$.

The compressive-shear strength of the joints were determined according to the industrial standard of the company DELO Industrie Klebstoffe GmbH \& Co. KG. The test is carried out in quasi-static conditions at constant strain rate using a simple fixture, ensuring that the load causes shear stress at the joint of the overlapping ceramic specimens. The ultimate compressive shear strength is calculated as

$$
\tau=\frac{F_{\max }}{A}=\frac{F_{\max }}{l_{j} b}
$$

where $\tau$ is the compressive-shear strength, $F_{\text {max }}$ is ultimate load, $l_{j}$ is length of the joint and $b$ is width of the specimen.

Thermal shock resistance was determined by heating the set of specimens (10 pcs) in air up to $350^{\circ} \mathrm{C}$ with temperature increase rate of $10 \mathrm{~K} / \mathrm{min}$. After soaking time of $30 \mathrm{~min}$, the specimens were cooled in water $\left(15^{\circ} \mathrm{C}\right)$. The shock resistance was evaluated on the basis of failure of the joint or specimens mass loss of $10 \%$. The test was repeated at a higher temperature with the temperature interval of $20 \mathrm{~K}$. The criterion for thermal shock resistance was the temperature by which less than $50 \%$ of specimens failed.

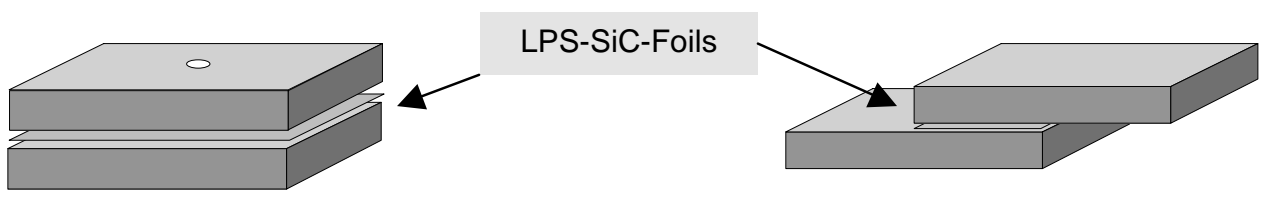

Fig. 3. Realized geometries of joints. 


\section{RESULTS AND DISCUSSION}

The diffusion joining process is described by the following phases (Fig. 4):

- the combination of segments of the base material to be joined $\left(\mathrm{Si}_{3} \mathrm{~N}_{4}-\mathrm{Si}_{3} \mathrm{~N}_{4}\right)$ and a joining foil containing the base material $\mathrm{SiC}$ with a gradually different composition;

- LPS-SiC foils with sinter additives of about $30 \%$ between $\mathrm{LPS}-\mathrm{Si}_{3} \mathrm{~N}_{4}$ ceramic with $5 \%$ sinter additive;

- to improve the contact an additional pressure on the components (phase 2);

- at the joining temperature the diffusion of the flux, formed at high temperatures, into the base material starts and an equalisation of the sinter additive concentration takes place, which leads to the formation of the diffusion and a joining zone (phase 3);

- the disappearance of the differences between the joining zone and the base material (phase 4).

For LPS-SiC foil laminates, sintered at $1700^{\circ} \mathrm{C}$ in argon, the CTE was determined. Results of the measurements are given in Fig. 5.

The LPS- $\mathrm{Si}_{3} \mathrm{~N}_{4}$-ceramic with a $5 \%$ of sinter additive concentration shows a constant expansion gradient in a temperature range of $100-900^{\circ} \mathrm{C}$ of $5 \times 10^{-6} \mathrm{~K}^{-1}$. LPS-SiC foils with different sinter additive concentrations show a smaller difference compared to the LPS-Si $\mathrm{N}_{3} \mathrm{~N}_{4}$-ceramic. The difference of the expansion coefficients is about $2 \times 10^{-6} \mathrm{~K}^{-1}$ and it is a requirement for a low-stress joint. During the diffusion joining process concentration equalization of the sinter additives takes place and the equalizing effect of CTE is observed.

Results of SEM and EDX analyses of the LPS-Si $\mathrm{N}_{4}$-ceramic joint at a joining temperature of $1600^{\circ} \mathrm{C}$, carried out in order to evaluate the quality of joints, are given in Fig. 6. The joining zone shows a homogeneous ceramic joint with optimal contact on the surfaces between LPS-Si $\mathrm{N}_{4}$-base material and LPS-SiC foil. Neither a pore phase nor cracks on the surface were observed. The EDXanalysis proves that the gradients of the sinter additives $\mathrm{Y}_{2} \mathrm{O}_{3}$ and $\mathrm{Al}_{2} \mathrm{O}_{3}$ between the LPS-Si $\mathrm{N}_{4}$-base material and the LPS-SiC foil are nearly constant. The concentration difference of the sinter additives was completely reduced.

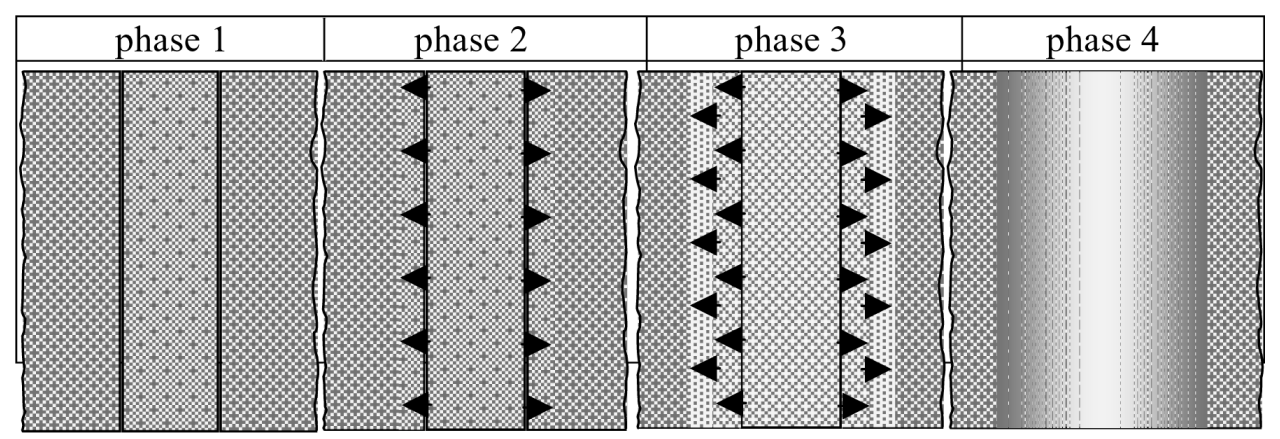

Fig. 4. Joining mechanism of $\mathrm{Si}_{3} \mathrm{~N}_{4}$ ceramics using ceramic foils. 


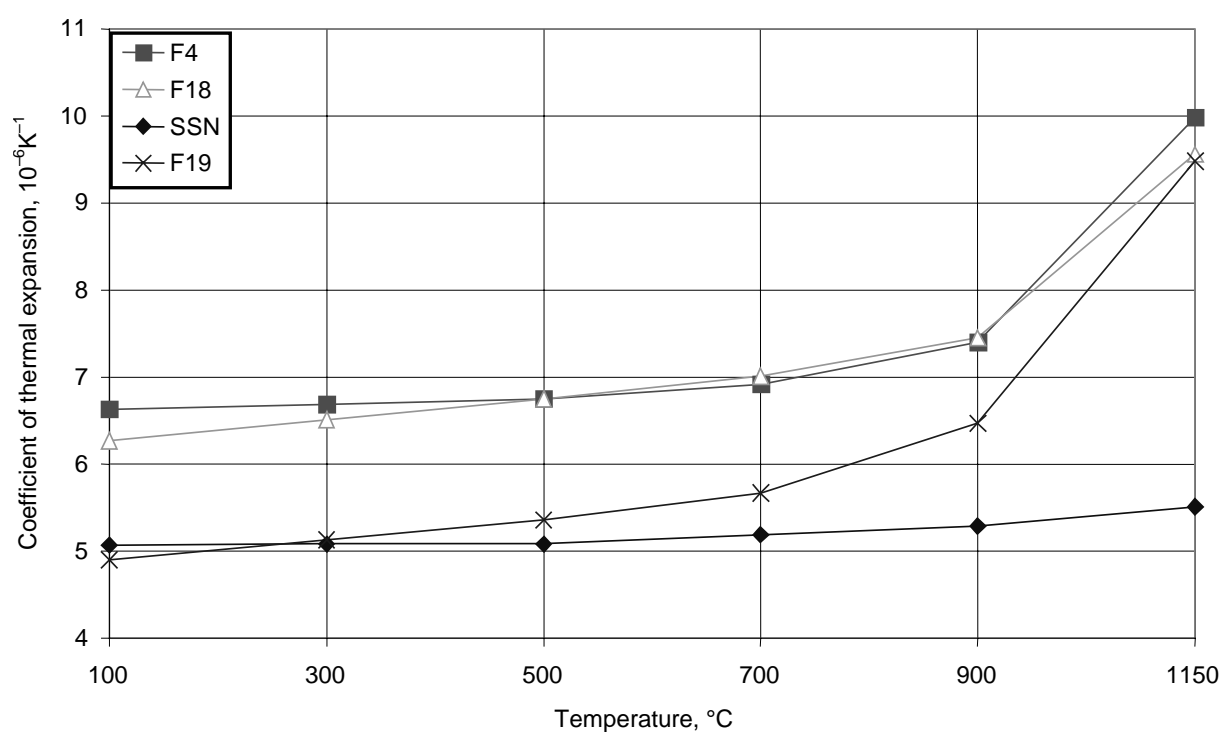

Fig. 5. Thermal expansion behaviour of LPS-SiC foils: SSN - sintered silicon nitride with a $5 \%$ sinter additive, $\mathrm{F} 4-60 \mathrm{wt} \% \mathrm{SiC}$ and $40 \mathrm{wt} \% \mathrm{Al}_{2} \mathrm{O}_{3} / \mathrm{Y}_{2} \mathrm{O}_{3} ; \mathrm{F} 18-30 \mathrm{wt} \% \mathrm{SiC}$ and $70 \mathrm{wt} \% \mathrm{Al}_{2} \mathrm{O}_{3} / \mathrm{Y}_{2} \mathrm{O}_{3}$; $\mathrm{F} 19-70 \mathrm{wt} \% \mathrm{SiC}$ and $30 \mathrm{wt} \% \mathrm{Al}_{2} \mathrm{O}_{3} / \mathrm{Y}_{2} \mathrm{O}_{3}$.

(a)

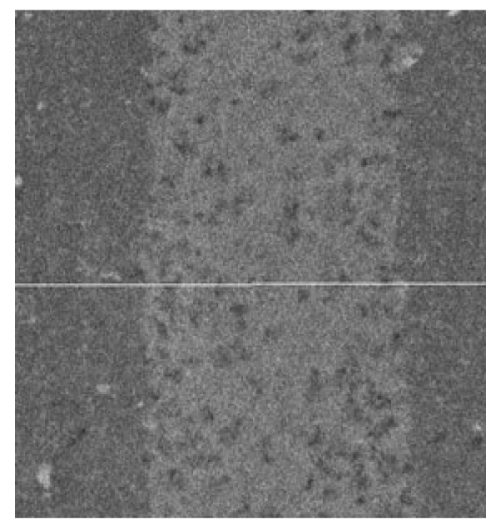

(b)

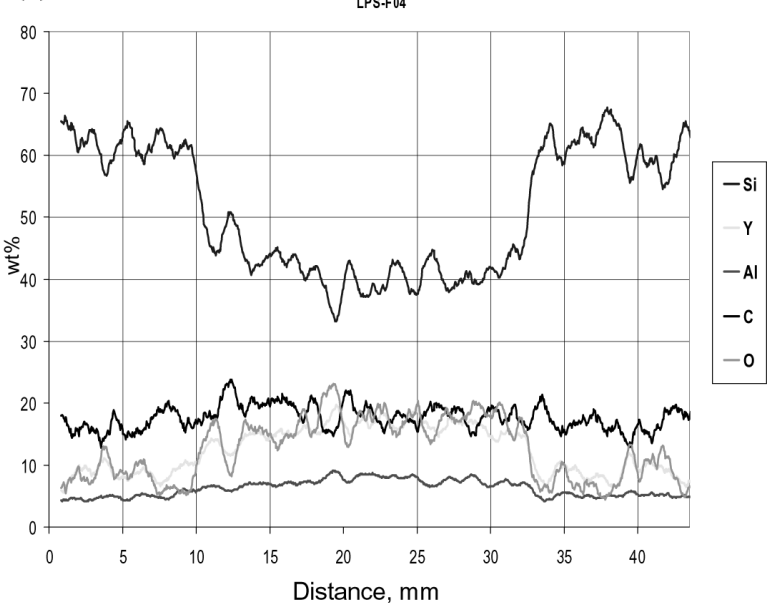

Fig. 6. Joining zone LPS/ $\mathrm{Si}_{3} \mathrm{~N}_{4}$-LPS-SiC-foil-LPS/Si $\mathrm{N}_{4}$ (a) and EDX-analysis (Line-Scan) (b).

Compressive and shear strength were determined on overlapping LPS-Si ${ }_{3} \mathrm{~N}_{4-}$ ceramic joints (Fig. 7). Depending on the concentration of sintering additives $\mathrm{Al}_{2} \mathrm{O}_{3}$ and $\mathrm{Y}_{2} \mathrm{O}_{3}$, high strength values of over $100 \mathrm{MPa}$ were obtained. The ceramic joining foils F20, F21 and F22 were additionally doped with $\mathrm{SiO}_{2}$. The strength decreased under $100 \mathrm{MPa}$. The $\mathrm{SiO}_{2}$ phase increased the brittleness at the expense of the compressive and shear strength. 


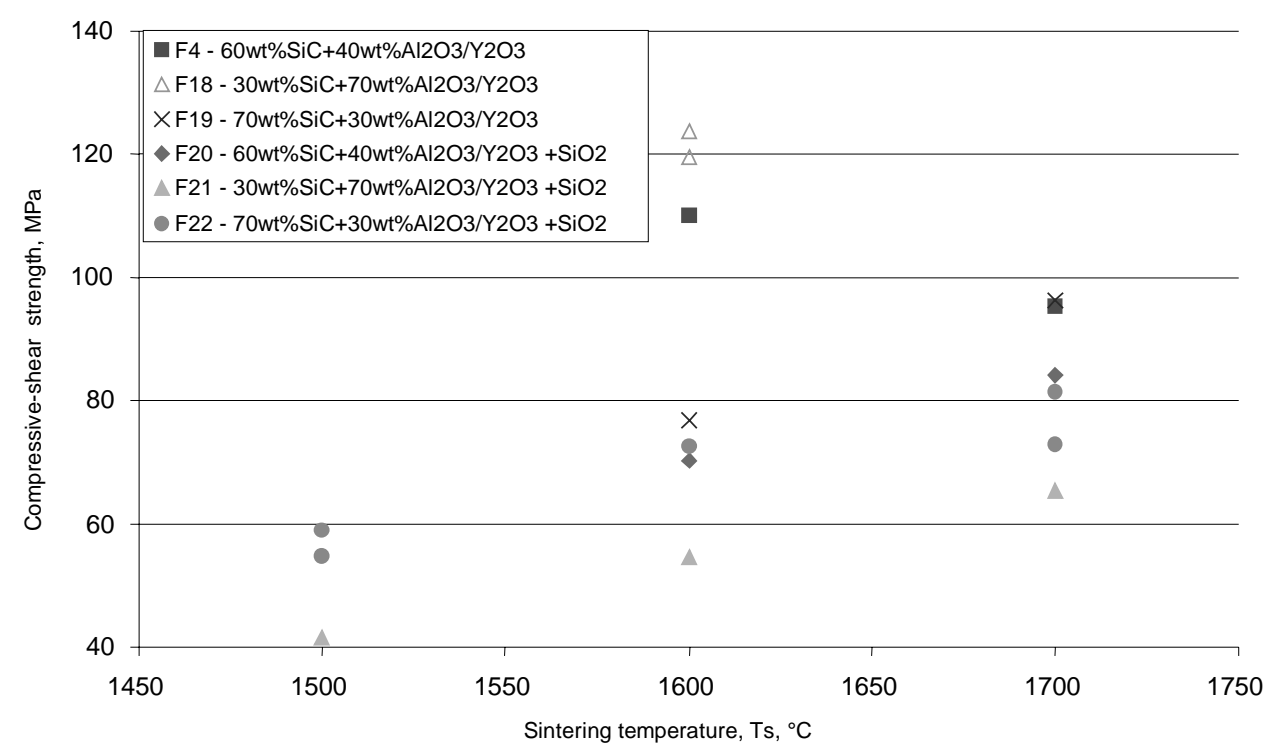

Fig. 7. Influence of the joining temperature on the compressive-shear strength of joints.

A functional dependence of the strength on the joining temperature was found. At a joining temperature of $1500^{\circ} \mathrm{C}$ the foil broke, at $1600^{\circ} \mathrm{C}$ the foil as well as the base material broke. A breakdown of the base material could be detected at a joining temperature of $1700^{\circ} \mathrm{C}$ (Fig. 8). These joints have a strength, which is similar to that of the base materials $\left[^{8}\right]$. Similar results were obtained in our previous studies with silicon carbide and other ceramics $\left[{ }^{9,10}\right]$.

The thermal shock resistance of the joints reaches up to $400^{\circ} \mathrm{C}$ for the specimens with given geometries.

(a)

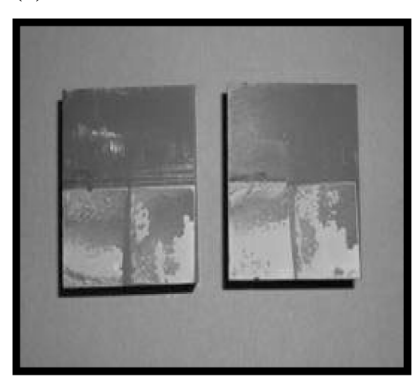

(b)

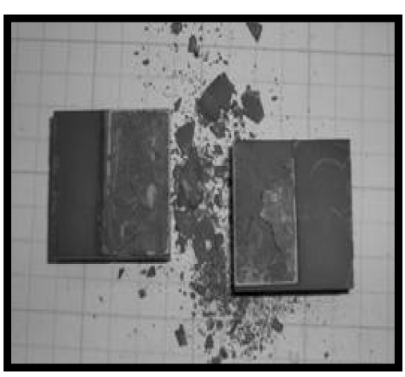

(c)

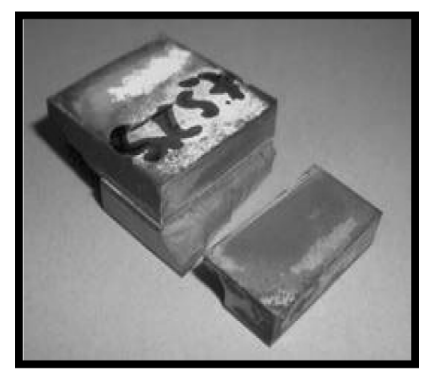

Fig. 8. Breaking images of joints: (a) joining temperature $1500^{\circ} \mathrm{C}$; (b) $1600^{\circ} \mathrm{C}$; (c) $1700^{\circ} \mathrm{C}$. 


\section{CONCLUSIONS}

The diffusion joining of $\mathrm{Si}_{3} \mathrm{~N}_{4}$-ceramic with adjusted ceramic joining foils is a promising way among the existing joining procedures. Substantially equal materials are essential for the formation of a ceramic joint in the joining zone. The material characteristics match the ceramic to be joined. The mechanical properties and thermal endurance of the joints do not change. A high vacuum tightness of over $10^{-7} \mathrm{mbar} 1 / \mathrm{s}$ was measured. These research results are the basis for a modular joining of ceramic housings or coolers. This joining principle can be applied to other ceramic materials (silicon carbide and aluminium nitride).

\section{ACKNOWLEDGEMENTS}

The presented results are extracts from an ongoing research project within the framework of the BMWi programme INNO-WATT - FuE-Projekt Reg. VF080016 "Diffusion joining of ceramics", Bundesrepublik Deutschland. Special thanks to Prof. Priit Kulu and Prof. Renno Veinthal from Tallinn University of Technology, Department of Materials Engineering, Estonia.

\section{REFERENCES}

1. Larker, R. Diffusion Bonding of Structural Ceramics to Superalloys by HIP. PhD Thesis, Lulea University of Technology, 1992.

2. Dobedo, R. S. and Holland, D. Bonding silicon nitride using glass-ceramic. Key Eng. Mater., 1995, 99-100, 233-240.

3. Johnson, S. M. and Rowcliffe, D. J. Mechanical properties of joined silicon nitride. J. Am. Ceram. Soc., 1985, 68, 468-472.

4. Lewinsohn, C. A. and Jones, R. H. A Review of Joining Techniques for SiCf/SiCm Composites for First Wall Applications. Fusion Materials Semiannual Progress Report for the Period Ending June 30, Oak Ridge National Laboratory, Oak Ridge, 1998.

5. Xie, R.-J., Mitomo, M., Huang, L.-P. and Fu, X.-R. Joining of silicon nitride ceramics for hightemperature applications. J. Mater. Res., 2000, 15, 136-141.

6. Zhou, F. Joining of silicon nitride ceramic composites with $\mathrm{Y}_{2} \mathrm{O}_{3}-\mathrm{Al}_{2} \mathrm{O}_{3}-\mathrm{SiO}_{2}$ mixtures. J. Mater. Process. Technol., 2002, 127, 293-297.

7. Dahms, S., Kulu, P., Veinthal, R., Basler, U. and Sändig, S. Substance-to-substance joining of quartz glass. Estonian J. Eng., 2009, 15, 151-167.

8. Patent DE 102008040260 A1 2009.01.15. Diffusionsgefügtes keramisches Bauteil und Verfahren zu seiner Herstellung. H.-P. Martin, 01705 Freital, DE; Richter, 01257 Dresden, DE; S. Dahms, 07745 Jena, DE, Offenlegungsschrift 15.1.2009.

9. Martin, H.-P., Dahms, S., Richter, H.-J. and Triebert, A. Diffusion joining of silicon carbide products. In Proc. Conference, MSE 2008. Nürnberg, 2008, C14-272.

10. Dahms, S., Martin, H.-P., Richter, H.-J. and Triebert, A. Diffusionsfügen von Keramiken. In AGW 3 - DVS-Kolloquium "Fügen von Metall, Keramik und Glas". TU Berlin, Füge- und Beschichtungstechnik, Produktionstechnisches Zentrum, 2009. 


\title{
Räninitriidkeraamika difusioonliitmine
}

\author{
Steffen Dahms, Felix Gemse, Ursula Basler, Hans-Peter Martin \\ ja Anke Triebert
}

Multifunktsionaalsete omadustega kõrgtemperatuursest ja kulumiskindlast keraamikast suurte ning keeruka kujuga detailide valmistamine üksikutest elementidest vajab uusi liitmistehnoloogiaid. Sel eesmärgil loodi paagutatud SiC baasil spetsiaalsed keraamilised fooliumid mitteoksiidkeraamika - räninitriidi $\left(\mathrm{Si}_{3} \mathrm{~N}_{4}\right)$ - difusioonliitmiseks. Selgitati välja fooliumi paagutuslisandite ja difusioonliitmise tehnoloogiliste parameetrite mõju saadud liidete omadustele. Paagutatud $\mathrm{Si}_{3} \mathrm{~N}_{4}$-fooliume kasutades on võimalik saada surve- ja vaakumtihedad difusioonliited, mis on piisavalt tugevad kasutamiseks temperatuuridel 1600 $1700^{\circ} \mathrm{C}$. 